\title{
A Madame SAND
}

"Esa roca arqueada con arte, obra maestra de antaño, ese peñasco de Tarascón solía alojar en otro tiempo los gigantes que habían descendido de las montañas de Foix, huesos excesivos darán fiel testimonio."

¡Oh, señor Du Bartas! Soy de tu linaje, yo que uno mi verso a tu verso de antaño; pero los verdaderos descendientes de los antiguos Condes de Foix necesitan testigos para hablar en nuestra época.

Pasé cerca de Salzburgo bajo rocas trémulas, allí La Cigüeña de Austria alimenta a los Milanos, Barbarroja y Ricardo consagraron este refugio.

La nieve impera en la cima de sus picos que nadie ha franqueado; y son, me han dicho, las osamentas blanquecinas de antiguos montes consumidos por el mar del Diluvio. 